\title{
The School as an Influencing Factor of Truancy
}

\author{
Dirk Baier*
}

\author{
Zurich University of Applied Sciences, Departement Social Work, Institute for Delinquency and Crime \\ Prevention, Pfingstweidstrasse 96, P.O. Box 707, CH - 8037 Zürich, Switzerland
}

\begin{abstract}
As previous research has shown, truants have a higher risk of becoming delinquent. However, the causes of truancy are only seldom analyzed in criminological research. Since truancy is a school related behavior, it can be assumed that school factors play a major role in causing it. Using a German wide representative sample of almost 40,000 pupils of the ninth grade (mean age: 15 years; 50.3 percent male) from 1,200 schools several school factors and their relationship with truancy are tested. These factors are theoretical derived from a push-and-pull-model. Push factors are for instance teacher bullying or violent schoolmates, pull factors are responsive teachers and positive relationships with schoolmates. The results show that teacher bullying and low teacher control significantly increase truancy. Compared with individual risk factors like self-control or school achievement school factors are of lower importance. Additional analyses reveal that there are interaction effects between individual and school level variables: A high level of teacher bullying particularly increases truancy of pupils with bad grades.
\end{abstract}

Keywords: Truancy, adolescents, teacher, school.

\section{INTRODUCTION}

In the past decade, there have been an increasing number of studies that focus on the prevalence, causes and prevention of truancy (see e.g. Attwood and Croll, 2006; Reid, 2005). One reason for the growing interest in this subject is that different studies have shown a strong correlation between truancy and a range of other deviant or delinquent behaviours (e.g. Loeber and Dishion 1983; Mounteney, Haugland, and Skutle 2010). Truants tend to commit more often crime against property as well as violent crime (e.g. Rabold and Baier 2007: 32-33). This correlation can be explained by at least two theoretical approaches. In line with control theory by Hirschi (1969) one may argue that truancy goes along with a weakened bond towards important socializing persons like parents or teachers (low attachment). Hence, commitment to conventional goals, involvement in conventional activities and belief in social rules are reduced, which in turn raises the risk of becoming delinquent. On the other hand the theory of differential association (Sutherland 1924) would stress the role of delinquent peers in the truancydelinquency relationship. Because truants are rejected in part by their classmates resp. have a stronger desire to find similar friends they more often belong to delinquent peer groups. Here deviant attitudes are stabilized and effective ways of playing truant or committing other deviant acts are learned. Accordingly, having delinquent friends is proven to be one of the strongest predictors of delinquent behaviour (e.g. Warr 2002).

*Address correspondence to this author at the Zurich University of Applied Sciences, Departement Social Work, Institute for Delinquency and Crime Prevention, Pfingstweidstrasse 96, P.O. Box 707, CH - 8037 Zürich, Switzerland; Tel: +41 5893489 04; E-mail: dirk.baier@zhaw.ch
Despite the studies published to date, there is still need for further research on truancy, especially on the topic of the influencing factors of that behaviour. While truancy is an expression of problems in, among other things, the family (e.g. McNeal 1999), it is a genuine school-related behaviour that should be influenced by prevailing conditions at school. Thus the question is what school factors influence truancy. It appears that, when asked why they skip school, truants often cite not wanting to go to school, wanting to stay in bed, and friends' behaviour and attitudes (see, e.g. Baier 2011: 77). Nonetheless, it can be assumed that, for example, one reason for 'not wanting to go to school' is linked with poor identification with school - something that should be influenced by the school itself. At the moment, there are only a few findings available on school-related influencing factors of truancy (e.g. Kimberly and Huizinga 2007). Using a model which differentiate between push and pull factors, this paper thus focuses systematically on such school-related factors.

\section{THEORETICAL FRAMEWORK AND HYPO- THESES}

The notion that a child's behaviour is influenced by factors such as the school attended or the home neighbourhood is nothing new in sociological research. This was developed in, among others, social disorganisation theory (Shaw and McKay 1969), which assumes that relative to the neighbourhood in which a child lives, a disorganised structure fosters juvenile crime. Indicators of disorganised structure are high poverty rates, high ethnic heterogeneity, and high mobility. It is assumed that such structural conditions make it difficult for people living in a neighbourhood to 
establish close social relationships. They have little in common with each other - in terms of values, for example. In turn, a lack of social relationships can result in lower levels of cohesion. Sampson, Raudenbush and Earls (1997) speak of the low collective efficacy of disorganised neighbourhoods, which is defined by two factors: social cohesion and informal social control. Informal social control relate to the willingness of local people to intervene in cases of social disorder (e.g. gangs of youths hanging around, and damage to property). Such behaviour is primarily to be expected if local people know one another and there is consensus as to which type of social disorder they are not prepared to tolerate.

Social disorganisation theory points to the role of social relationships in the development of delinquent behaviour, assigning a key role to the social controls exercised by adults. This assumption can easily be transferred to schools and to the behaviour demonstrated by truants. In schools, the adults are teachers. A school's teaching staff can differ in terms of structure (e.g. ethnic and gender mix). Of greater importance than the demographic composition of teaching staff is, however, how members of staff behave. Different studies confirm that the form of control exercised by teachers is of key importance in curbing deviant behaviour in schools. For instance, Baier and Pfeiffer (2011) show that violent behaviour is less prevalent in schools where teachers are more willing to intervene to stop acts of violence. Looking at truancy, there is evidence that the higher the visibility of teacher-exercised control, the lower the level of truancy in the school concerned (see Wilmers et al. 2002: 303). Thus, Hypothesis 1 assumes that young adolescents play truant less often if the teaching staff at their schools impose stricter controls.

However, socio-cultural processes in schools are not adequately captured by the control dimension. To make assumptions regarding additional influencing factors of truancy, it would appear useful to apply a push and pull model. A model of this kind is to be found in migration research (see Lee 1966) and segregates for factors that either cause people to leave a neighbourhood (push) or make a neighbourhood particularly attractive (pull). Going to school represents a form of migration, which is why it makes sense to make use of this model. Certain school characteristics either attract or repel students. In the following, focus is placed on relationships between teachers and students, and among students themselves. These relationships can serve both as push and as pull factors in each case. There are thus four relationship dimensions in schools:

1. Pull factor: Positive teacher-student relationship. In their analysis, Lee and Burkam (2003) state that of the factors that influence premature school leaving which they covered in their study, the strongest influence comes from a positive teacher-student relationship. The more positive the relationship within a school, the fewer the students who leave school prematurely. Students were asked how much effort teachers put into looking after students, whether teachers were interested in the students, and whether they addressed students' problems and needs. Teachers who are open to students and take time for them signal respect and acceptance, and boost students' wellbeing. Students who experience this kind of treatment ought to be more willing to go to school. Hypothesis 2a therefore suggests that truancy is less prominent in schools where teachers respond to students in a positive way.

2. Push factor: Negative teacher-student relationship. The opposite effect can be expected from a negative teacher-student relationship. This is confirmed by some research findings. Reynolds et al. (1980) report that schools experience higher truancy rates if the school management is strict and unfriendly towards students. Moos and Moos (1978) find that students in classes with less supportive teaching staff play truant more often. And in various surveys of students who skip school, respondents frequently state that their relationship with teachers is poor (see Ricking 2003: 136). One specific form of negative teacher behaviour is aggression. That teachers are not only victims of violent attacks by students, but that they themselves demonstrate verbal, relational and physical aggression towards students is analyzed very seldom (e.g. Baier et al. 2009: 57). Such behaviour is bound to frighten off students; they avoid exposing themselves to attacks from teachers. Hypothesis $2 b$ thus suggests that truancy is more prevalent in schools where teaching staff have a negative attitude towards students and especially in schools where teachers behave aggressively towards students.

3. Pull factor: Positive student-student relationship. An attraction or repulsion effect of social 
relationships can also be assumed from studentstudent relationships. There is scarcely any empirical research into this aspect. However, it would appear plausible to formulate Hypothesis $2 \mathrm{c}$ as follows: Positive relationships between students at school increase students' willingness to go to school. Positive relationships between students include friendships. A large circle of friends at school should thus result in students not needing to seek peer recognition outside the school. Students who encounter individuals at school who they regard as friends should be highly motivated to attend school regularly.

4. Push factor: Negative student-student relationship. If friendly relationships at school are rare, then a factor protecting against truancy is lost. Moos and Moos (1978) have shown that a competitive or hostile classroom environment goes hand in hand with higher rates of absenteeism. A competitive climate is likely to prevent students from forming friendly relationships. And in addition, negative studentstudent relationships are seen to foster violent behaviour. Where students perceive a heightened level of violence at school, the rate of unexcused absence should be higher. Acts of violence among peers are equally as adverse as violent behaviour shown by teachers. The spectrum of behaviours among students ranges from verbal aggression to relational and physical attacks. Hypothesis $2 \mathrm{~d}$ thus suggests that truancy is higher in schools where negative student-student relationships exist and where students exercise violence against one another.

Most existing studies on truancy focus on influencing factors at individual level. As a result, they have identified key influencing factors which should be considered when analysing the effects of school factors because isolated analysis of school factors runs risk of their effect being over-estimated. In the past, focus has been placed on, among other things, the influence of school performance and school failure on truancy (see e.g. Ricking 2003: 127). This results in "regular truants [...] are almost exclusively among the losers in the school performance stakes" (ibid.: 127). Hypothesis 3 thus suggests that students who perform poorly at school are more likely to play truant than those who perform well. When searching for an explanation of this effect, it must be remembered that people avoid situations that lead to adverse experiences. The experience of failing to meet certain requirements or expectations, meaning not being good at school, can be deemed an adverse experience. Students retreat and avoid going to school. However, this effect is not likely to be evident to the same extent in all schools. The adverse experience based on grades can be compensated for by intact social relationships. These signal to the student that attaining poorer marks than others does not make them less valued as a person. It is thus assumed that (Hypothesis 3a), in schools with positive teacher-student and student-student relationships, the influence of poor school performance is less intense, and that in schools with negative teacher-student and student-student relations, poor school performance is particularly important in explaining the occurrence of truancy.

Further influencing factors of truancy can be attributed to socialisation situations beyond the school environment. Studies have shown that the parental home plays a key role. A conflict-ridden parent-child relationship appears to foster truancy levels. Wilmers et al. (2002) showed that serial truants are four times more likely to have experienced serious parental violence than non-truants. Hypothesis 4a thus suggests that students who experience parental violence are more likely to avoid going to school.

One explanation for this can be seen in that parents who subject their children to violence promote the development of personality traits that make deviant and delinquent behaviour more likely. This is addressed in self-control theory (Gottfredson and Hirschi, 1990). Poor self-control is in turn a risk factor for various forms of deviant behaviour (among others Vazsonyi et al. 2001), because individuals with poor self-control are unable to estimate the long-term consequences of their actions. The short-term benefits from actions such as truancy - that they allow the truant to pursue recreational activities instead of going to school - are placed in the forefront, while the consequences go unconsidered. Hypothesis $4 \mathrm{~b}$ thus assumes that, individuals with poor self-control play truant more often than those with high self-control.

Also, a range of studies show that truancy is a behaviour that is fostered by friends. Wagner, Dunkake and Weiß (2004) show that contact with friends who play truant significantly increases the likelihood of a child staying away from school. This effect can be explained in various ways. On the one hand, truant friends act as role models from whom truancy is learned. On the other hand, groups of truant friends can put pressure on a single child to act like the rest of 
the group. Additionally, attaining acceptance within the group is likely to play a role in a child playing truant. Hypothesis $4 \mathrm{c}$ thus suggests that, students with friends who play truant will frequently play truant themselves.

In addition to the factors cited above, a range of demographic factors should also be taken into account in the empirical analyses even though research findings on such factors are not always clear-cut. Demographic factors include gender, ethnic origin and school type. With regard to gender, Ricking (2003: 125) states that neither in German-speaking nor in Englishspeaking research is absenteeism seen as clearly the domain of either male or female students. In contrast to this, Baier et al. (2009: 76) report that males play more often repeatedly truant than females so it seems necessary to control for gender in multivariate analyses. When it comes to the type of school attended, the highest truancy rates are seen in lower school types. On the question of whether an immigrant background influences truancy, only few studies exist. It can, however, be assumed that children and young adults with migrant background more often play truant. As Baier et al. (2009) show, members of all migrant groups covered by the survey play truant more often than their indigenous peers.

\section{SAMPLE AND MEASUREMENT INSTRUMENTS}

\subsection{Sample}

In 2007 and 2008, the Criminological Research Institute of Lower Saxony conducted a representative nationwide survey of ninth grade school pupils, with the main focus on the investigation of violent behaviour (Baier et al. 2009) ${ }^{1}$. Various other forms of deviant behaviour were asked about in the same survey, including truancy. The sample was drawn for the survey in two stages: First, all 440 rural and urban districts in Germany were grouped into ten district categories based on their inhabitant number. Rural and urban districts were then selected for the survey at random from these district categories in proportion to the districts' relative shares in the categories. The plan was to survey a total of 50,000 adolescents - every second school pupil in each selected district. The outcome of the random selection comprised 61 rural and urban districts from which, in the second selection stage, school classes were selected at random for the

\footnotetext{
${ }^{1}$ The survey was spread across two years because it took longer to reach a compromise on data protection in some German federal states than in others.
}

survey. This selection was made in accordance with the division of schools into school types. If a district had all three types of secondary school found in Germany, classes were specially selected for each school type according to the share of all schools accounted for by that type. In this way, 3,052 classes were selected for the survey, of which 2,131 took part. These classes consisted of 71,891 pupils, of whom 44,610 were surveyed. The response rate was thus 62.1 percent. The questionnaire survey of school pupils was carried out in the classroom context in the presence of a test administrator and mostly also a teacher.

The hypotheses set out in the preceding section were tested on the basis of a reduced sample. This is necessary for the purpose of investigating schoolrelated factors for their influence on truancy. First of all, classes were surveyed in a total of 1,206 identifiable schools, giving an average of 1.7 classes per school. Between one and seven classes were surveyed in each school. To permit an assessment of school characteristics, pupils' responses were aggregated at school level. Schools where fewer than five pupils were surveyed are not included in the following. In addition, it was not possible to include pupils who could not be assigned to schools due to strict anonymisation rules in a number of the federal states. Finally, respondents were removed from the data for whom a value was missing for at least one central study variable. In the end, the analysis covered 39,301 pupils from 1,198 schools ${ }^{2}$. Responses from between five and 163 pupils were available for each school. The mean age of this sample is 15 years; 50.3 percent were male, 73.5 percent of German origin.

\subsection{Measurement Instruments}

The aim of this paper is to explain truancy behaviour by a range of school factors. Two forms of truancy were asked about in the 2007/2008 schools survey: Lesson-by-lesson truancy ("How many individual lessons did you skip in the last half school year?") and full day truancy ("How many whole days did you skip in the last half school year?"). The analysis will focus on full day truancy as this can be interpreted as a more pronounced expression of deviant behaviour. Also, lesson truancy doubtless more frequently involves conscious avoidance of specific

${ }^{2}$ It should be noted that school characteristics were determined on the basis of responses from all respondents (rather than only those from the reduced sample) in order to draw on the largest possible pool of information. 
Table 1: Measurement and Descriptive Statistics for School Variables

\begin{tabular}{|c|c|c|c|}
\hline & Measurement & Mean/SD (pupils) & $\begin{array}{l}\text { Mean/range } \\
\text { (schools) }\end{array}$ \\
\hline $\begin{array}{l}\text { Teacher-related pull factor: } \\
\text { Responsiveness to pupils }\end{array}$ & $\begin{array}{l}\text { Score for German, mathematics, sports and history } \\
\text { teacher: How fair is the teacher and how well does the } \\
\text { teacher provide support with problems }(1=\text { low; } 6=\text { high); } \\
\text { correlation between two scores } r \geq .62 ; \text { reliability for the } \\
\text { four teachers, Cronbach's alpha }=.66 \text {; mean scale }\end{array}$ & $4.25 / 0.94$ & $4.28 / 2.99-5.68$ \\
\hline $\begin{array}{l}\text { Teacher-related push factor: } \\
\text { Aggression (bullying) }\end{array}$ & $\begin{array}{c}\text { In last half school year: ridiculed by teacher, treated meanly } \\
\text { by teacher }(0=\text { never, } 3=\text { at least once a month); } r=.60 ; \\
\text { maximum scale }\end{array}$ & $0.56 / 0.84$ & $0.54 / 0.00-1.75$ \\
\hline Control by teachers & $\begin{array}{l}\text { Single item: Teachers ask for reasons for absence }(1=\text { not } \\
\text { true; } 4=\text { exactly true })\end{array}$ & $2.96 / 0.91$ & $2.98 / 1.75-4.00$ \\
\hline $\begin{array}{l}\text { Pupil-related pull factor: Friendship } \\
\text { integration }\end{array}$ & $\begin{array}{c}\text { Score for how popular with other pupils/how many friends } \\
\text { in school }(1=\text { not true; } 4=\text { exactly true); } r=.52 ; \text { mean } \\
\text { scale }\end{array}$ & $3.09 / 0.66$ & $3.08 / 2.07-3.83$ \\
\hline $\begin{array}{l}\text { Pupil-related push factor: } \\
\text { Aggression (bullying) }\end{array}$ & $\begin{array}{l}\text { In last half school year: teased, excluded or ignored by } \\
\text { other pupils }(0=\text { never; } 3=\text { at least several times a month); } \\
\text { Cronbach's alpha }=.69 ; \text { maximum scale }\end{array}$ & $0.79 / 0.96$ & $0.77 / 0.00-2.00$ \\
\hline $\begin{array}{l}\text { Pupil-related push factor: } \\
\text { Aggression (violence) }\end{array}$ & $\begin{array}{l}\text { In last half school year: hit, extorted }(0=\text { never; } 3=\text { at least } \\
\text { several times a month; } r=.24 ; \text { maximum scale }\end{array}$ & $0.29 / 0.64$ & $0.30 / 0.00-1.33$ \\
\hline
\end{tabular}

teachers or subjects, whereas full day truancy means avoiding all lessons and thus school as a whole. It therefore appears plausible to investigate relationships between school factors and full day truancy. In total, 26.5 percent stayed away from school for at least one full day without permission.

Table 1 show the school-related factors included in the analysis as explanatory variables. All of these variables were asked about at individual level as a personal scale rating, but then aggregated at school level as the mean of the individual ratings. Table 1 therefore includes descriptive statistics both for respondents and for schools. Presentation of a standard deviation was dispensed with for schools; instead, the lowest and the highest school value is shown to underscore that sufficient variance exists at school level.

With regard to teachers, responsiveness was asked about as a pull factor. For four teachers, it was asked how fair they are towards pupils and how well they support them with problems. The mean of these two scores was calculated, and then likewise the mean of the scores for the four teachers. The theoretical mean for this scale would be 3.5 ; the empirical mean is 4.25 , which means more pupils assess their teachers positively than negatively. As with the other variables, the school-level mean is almost identical with the individual-level mean. At the same time, it is shown that there are schools with less responsive teachers and schools with high responsive teachers.
A potential push factor on the teacher's side is aggressive conduct towards pupils. Physical violence is the exception here, as the findings of the 2007/2008 schools survey demonstrate (Baier et al. 2009: 57); verbal forms of aggression and bullying are more common. Use is therefore made of the pupils' responses on whether they had been ridiculed or treated meanly. The maximum score is used for this purpose. For example, if a pupil said they had been ridiculed at least several times a month but subjected to mean treatment only once or twice a month, the score for being ridiculed is included in the analysis ${ }^{3}$.

As a further factor describing teacher behaviour, a question was included on how school attendance was controlled. Pupils were asked to say whether teachers ask about reasons for absence. Where they do not, attendance control is low. A little over half of the pupils agree that such control is strong or fairly strong. Once again, marked differences can be seen between schools.

On the pupils side, an aspect included as a pull factor is the level of friendship integration. The pupils should answer the two items "I have many friends in my class" and "I am popular with my classmates". The mean value demonstrates that more pupils are

\footnotetext{
${ }^{3}$ The original response choices were on a six-point scale. As the responses 'once a week' and 'several times a week' were chosen only rarely, however, these were merged into 'several times a month'.
} 
Table 2: Correlations between School Variables (First Value: Pupils; Second Value: School)

\begin{tabular}{|c|c|c|c|c|}
\hline & $\begin{array}{c}\text { Teachers: } \\
\text { responsiveness to pupils }\end{array}$ & $\begin{array}{c}\text { Teachers: } \\
\text { Bullying }\end{array}$ & $\begin{array}{c}\text { Teacher } \\
\text { control }\end{array}$ & $\begin{array}{c}\text { Pupils: } \\
\text { Integration }\end{array}$ \\
\hline \hline Teachers: Bullying & -.28 & - & - & - \\
Bullying
\end{tabular}

All correlations significant at $p<.05$ (except correlations marked 'n.s.' for 'not significant').

perceived as integrated than not integrated. There are significant differences in the degree of integration between schools, however. By way of push factors, the survey once again asked about bullying among pupils. In addition, experience of physical violence was included, which at schools is more common in the form of assaults by other pupils than of assaults by teachers ${ }^{4}$. There are schools where not a single pupil reports being a victim of bullying or violence; at others, by contrast, fairly large numbers of pupils report such experience.

Table 2 demonstrates that the surveyed school variables are to a very great extent independent variables, the correlations between them tending to be small. This applies both at individual and at school level. Medium correlations are found for teacher responsiveness and teacher bullying. Where teachers are perceived as fair and supportive, they are more rarely aggressive towards pupils. With regard to pupils, it is seen that bullying and physical forms of violence go hand in hand. Another interesting observation is that where teachers bully, pupils too more frequently show corresponding aggressive behaviours. In addition, greater responsiveness by teachers goes hand in hand with greater attendance control. And greater integration of pupils goes along with less frequent bullying and violence. The remaining correlations are negligible.

Another factor to be investigated is the influence of school performance on truancy. Pupils were asked to

\footnotetext{
${ }^{4}$ The correlation between items relating to physical violence is moderate $(r=$ .24). The items are nonetheless combined into a maximum scale. This appears justified because the scale (like the other maximum scales reflecting behaviours) is to be interpreted as an index. For an index, however, it is not a requirement that there has to be strong correlation between individual items, for example because not every school pupil who is hit also has to have experienced extortion or robbery.
}

state their grades in German, mathematics and history, using the grading scale prevalent in Germany (' 1 ' for excellent through to ' 6 ' for fail). The sports grade was also asked for, but this correlates poorly with the other grades and cannot therefore be considered indicative of a school pupil's average performance. As school grades and the other variables shown in Table $\mathbf{3}$ constitute individual risk factors for truancy, no schoolrelated variables are reported.

Further important factors influencing truancy are expected to be low self-control, experience of violence in the family, and association with truant friends. Low self-control is surveyed using the risk-seeking scale that goes back to Grasmick et al. (1993). That instrument also includes other scales for measuring other sub-dimensions of low self-control. Studies have shown, however, that risk-seeking is most strongly related to delinquent and deviant behaviour (see e.g. Wood, Pfefferbaum, and Arneklev 1993). Experience of parental violence was recorded in relation to the last twelve months, with questions on six different forms of violence each asked separately for the father and the mother. The maximum value was then taken for all items. The means presented in Table 3 thus show that 27 percent of respondents experienced at least one form of parental violence from at least one parent. Association with truant friends was measured using an item in which pupils were asked to state the number of friends who skipped school for at least one day in the last twelve months. No fewer than 70.6 percent said they had at least one such friend.

The following may be recorded regarding the demographic composition of the sample:

50.3 percent of respondents are male and 49.7 percent female 
Table 3: Measurement and Descriptive Statistics for Individual Variables

\begin{tabular}{|c|c|c|}
\hline & Measurement & Mean/SD \\
\hline Grades & Last report grades in German, mathematics and history ( $1=$ excellent; 6 = fail) & $3.00 / 0.73$ \\
\hline Self-control: risk-seeking & $\begin{array}{l}\text { Four-item scale, e.g. "I like taking risks simply because it's fun" ( } 1=\text { not true; } 4=\text { exactly true); } \\
\text { Cronbach's alpha }=.85 ; \text { mean scale }\end{array}$ & $2.11 / 0.79$ \\
\hline $\begin{array}{l}\text { Experience of parental } \\
\text { violence }\end{array}$ & $\begin{array}{l}\text { Six-item scale, e.g. whether clipped by father/mother in last } 12 \text { months }(0=\text { no violence } \\
\text { experienced; } 1=\text { violence experienced); maximum scale }\end{array}$ & $0.27 / 0.44$ \\
\hline $\begin{array}{l}\text { Association with truant } \\
\text { friends }\end{array}$ & $\begin{array}{l}\text { Single item: Number of friends who skipped at least one day's school in last } 12 \text { months (1 to } 5 \\
\text { friends: } 59.1 \% \text {; more than } 5 \text { friends: } 11.5 \% \text { ) }\end{array}$ & - \\
\hline
\end{tabular}

- $\quad 26.5$ percent of respondents have a migrant background. Migrant background was determined by asking respondents to state their own and their natural parents' country of birth and nationality.

- $\quad 11.9$ percent of the schools are in eastern Germany, and correspondingly 88.1 percent in western Germany or Berlin

- $\quad 37.0$ percent of the schools are a special school or a Hauptschule (lowest educational level in Germany), 36.4 percent Realschule or Gesamtschule (middle educational level in Germany), and 25.6 percent Gymnasium (highest educational level in Germany).

\section{FINDINGS}

The formulated hypotheses were tested using a number of binary logistic multilevel analyses. The dependent variable is full-day truancy, with the distinction made between truant and non-truant pupils. Multilevel analyses take into account the fact that pupils at a given school are not independent of each other in their responses (see e.g. Snijders and Bosker 2011). Independence of observations is a requirement for single-level regression analyses. The interdependence between observations as found here must be taken into account in the computation of standard errors. Multilevel analyses also make it possible to incorporate higher-level explanatory variables (in this instance: school-related factors) and to test whether those explanatory variables moderate individual interrelationships as posited in Hypothesis 3a. The software used to compute the various models was HLM $6.06^{5}$.

\footnotetext{
${ }^{5}$ On the school level there were no missing data. On the individual level there were missing data for gender, migrant background, experiences of parental violence and association with truant friends. These missing cases were
}

Model 1 in Table 4 is the 'null' model, containing no explanatory variables. This model is used to test whether schools significantly differ with regard to the proportion of full-day truants. This is indeed the case, as coefficient $\sigma_{\cup 0 j}$ shows. This model is also used to determine the intra-class correlation. This is 0.101 (not shown), meaning that a maximum of 10.1 percent of the variance in truancy is attributable to school factors. School conditions therefore play a role in the explanation of truancy. This continues to apply after incorporating a number of control variables, as Model 1a shows. The coefficients in this model show that male school pupils have a significantly lower risk of fullday truancy. The risk is 1.8 times as high for pupils with a migrant background than for indigenous Germans. Pupils from schools in eastern Germany feature significantly less frequently in the truants group, as do Realschule/Gesamtschule and Gymnasium school pupils (compared with special school/Hauptschule pupils). These four variables alone are capable of explaining 8.1 percent of the variance in full-day truancy. The intra-class correlation, however, is still significant $(0.060, p<.001)$, meaning that the proportion of truants still vary between schools.

The six school-related variables were therefore incorporated in the next step. Individual models were initially computed for this purpose, i.e. for each variable, it was separately tested whether the variable was related to truancy in the expected way. For clarity of presentation, the six models are not shown separately but are combined as 'Models 2'. As multiple models are included here, it is not possible to present the explained variance. The individual models confirm first and foremost that teachers influence truancy. In schools where teachers show greater responsiveness,

included in the analyses as missing cases. This is possible because all these variables are categorical, so for each variable a set of dummy variables had to defined, with the last dummy variable representing the missing cases. In none of the models missing cases dummy variables had a significant effect on truancy. 
lower bullying behavior and higher attendance control, pupils are significantly less likely to be found in the truants group. Social integration among pupils does not reduce truancy, nor does more frequent bullying increase it. Truancy is seen to be more common, however, where physical violence is more frequent among pupils.

The four variables shown in the individual models to be significant factors were then tested simultaneously with the control variables in Model 2a. Only teacher bullying and attendance control still showed a significant influence. Relative to Model 1a, the explained variance increased slightly to 8.3 percent, confirming that school factors are not to be neglected in the explanation of truancy. The intra-class correlation is $0.052(p<.001)$, meaning that the differences in the percentage of truants between schools are not fully explained by the school variables included in the model; this also applies for Models 3 and 4.

Model 3 additionally incorporates pupils' individual responses on teacher bullying and attendance control. This indicates a strict test of the influence of context variables as it looks at whether school variables aggregated from individual responses have any additional explanatory value. As the school variables are based on pupils' responses, there is always an correlation between the two variables. Incorporating the individual responses therefore means the inclusion of more closely correlated control variables. The findings from the model show that pupils who are themselves

Table 4: Factors Influencing Truancy (Binary Logistic Multilevel Analysis; Coefficient: $\operatorname{Exp}(B))$

\begin{tabular}{|c|c|c|c|c|c|c|}
\hline & Model 1 & Model 1a & Models 2 & Model 2a & Model 3 & Model 4 \\
\hline $\begin{array}{l}\text { Fixed effects: individual level } \\
\text { Gender: male } \\
\text { Origin: migrant background } \\
\text { Teachers: bullying } \\
\text { Teacher control } \\
\text { Grades } \\
\text { Risk seeking } \\
\text { Experience of parental violence } \\
\text { Assoc. with truant friends: No } \\
\text { Assoc. with truant friends: } 1 \text { to } 5 \\
\text { Assoc. with truant friends: }>5\end{array}$ & & $\begin{array}{l}0.926^{* *} \\
1.826^{* * *}\end{array}$ & & $\begin{array}{l}0.923^{* *} \\
1.822^{* * *}\end{array}$ & $\begin{array}{l}0.897^{* * *} \\
1.787^{* * *} \\
1.404^{* * *} \\
0.757^{* * *}\end{array}$ & $\begin{array}{c}0.781^{* * *} \\
1.533^{* * *} \\
- \\
0.788^{* * *} \\
1.566^{* * *} \\
1.555^{* * *} \\
1.294^{* * *} \\
\text { Reference } \\
4.036^{* * *} \\
10.335^{* * *}\end{array}$ \\
\hline $\begin{array}{l}\text { Fixed effects: school level } \\
\text { Teachers: responsiveness to pupils } \\
\text { Teachers: bullying } \\
\text { Teacher control } \\
\text { Pupils: integration } \\
\text { Pupils: bullying } \\
\text { Pupils: violence } \\
\text { Eastern Germany } \\
\text { Special school/Hauptschule } \\
\text { Realschule/Gesamtschule } \\
\text { Gymnasium }\end{array}$ & & $\begin{array}{l}\text { Reference } \\
0.656 \text { *** } \\
0.654^{* * *}\end{array}$ & $\begin{array}{l}0.767^{* * *} \\
1.659^{* * *} \\
0.573^{* * *} \\
0.805 \\
1.011 \\
1.274^{*}\end{array}$ & $\begin{array}{c}0.936 \\
1.480 * * * \\
0.601 * * * \\
- \\
- \\
1.125 \\
0.683^{* * *} \\
\text { Reference } \\
0.618^{* * *} \\
0.515^{* * *}\end{array}$ & $\begin{array}{c}- \\
1.108 \\
0.777^{* *} \\
- \\
- \\
- \\
0.667^{* * *} \\
\text { Reference } \\
0.602 \text { *** } \\
0.492^{* * *}\end{array}$ & $\begin{array}{c}- \\
- \\
0.800 * * \\
- \\
- \\
- \\
0.773^{* * *} \\
\text { Reference } \\
0.579 * * * \\
0.556 * * *\end{array}$ \\
\hline $\begin{array}{l}\text { Random effects } \\
\sigma_{\cup 0 j}(\text { constant) } \\
\text { Explained variance }(\%)\end{array}$ & $0.354^{* * *}$ & $\begin{array}{c}0.202^{* * *} \\
8.1\end{array}$ & $\begin{array}{l}- \\
-\end{array}$ & $\begin{array}{c}0.176^{* * *} \\
8.3\end{array}$ & $\begin{array}{c}0.197^{* * *} \\
12.4\end{array}$ & $\begin{array}{l}0.167^{* * *} \\
31.4\end{array}$ \\
\hline
\end{tabular}

${ }^{*} \mathrm{p}<.05,{ }^{* *} \mathrm{p}<.01,{ }^{* * *} \mathrm{p}<.001$ 
bullied by teachers more frequently stay away from school. Teacher bullying as a school-level factor is now found to be no longer significant. This implies an indirect explanation path for this school characteristic: At a school where teachers bully more frequently, a pupil has a greater risk of becoming a victim of such bullying. Pupils who are personally affected then also more frequently avoid school. Teacher control, on the other hand, is found to be significant as both at the individual and the collective level: Pupils who see that teachers exercise greater control skip school less frequently. And at schools where there is a high degree of control, there is generally less truancy regardless of how pupils themselves perceive teachers' control.

This influence of pupils' personal perception and the general level of teacher control at a school also remains significant when further individual risk factors are included (Model 4). All four additional factors correlate significantly with truancy: Poor grades, riskseeking, experience of parental violence and association with truant friends all increase the risk of truancy. The influence of friends is especially pronounced: Pupils with more than five truant friends are 10.3 times more likely to skip school for at least one day than pupils with no truant friends. The explained variance in Model 4 is 31.4 percent. Compared with the preceding models, it is thus confirmed that individual-level variables have a significantly stronger influence on truancy than schoollevel variables.

Model 4 demonstrates that poorer grades go hand in hand with a greater propensity towards truancy. This was expected in Hypothesis 3. It was also assumed that the influence of grades varies among schools and depends on school circumstances. Model 5 shows first of all that the relationship between grades and truancy varies significantly among schools $\left(\sigma_{U 1 j}\right)$. Poor grades thus indeed do not motivate pupils in all schools to engage in truancy to the same extent. To what degree the school factors influence the strength of that relationship was once again investigated in individual models (Models 6). A significant effect is found here for only one variable: teacher bullying. The associated coefficient can only be understood in relation to the coefficient for grades: Poor grades increase the risk of truancy; in schools where teachers bully more

Table 5: Factors Influencing Truancy (Binary Logistic Multilevel Analysis; Coefficient: Exp(B))

\begin{tabular}{|c|c|c|c|}
\hline & Model 5 & Models 6 & Model 6a \\
\hline \multicolumn{4}{|l|}{ Fixed effects: Individual level } \\
\hline Grades & $1.809 * * *$ & & $1.741^{* * *}$ \\
\hline Gender: male & & & $0.894^{* * *}$ \\
\hline Origin: migrant background & & & $1.727^{\star \star \star}$ \\
\hline \multicolumn{4}{|l|}{ Fixed effects: School level } \\
\hline Eastern Germany & & & $0.658^{* * *}$ \\
\hline Special school/Hauptschule & & & Reference \\
\hline Realschule/Gesamtschule & & & $0.635^{* * *}$ \\
\hline Gymnasium & & & $0.617^{* * *}$ \\
\hline Teachers: responsiveness to pupils * grades & & 0.964 & \\
\hline Teachers: bullying * grades & & 1.211 * & 1.258 * \\
\hline Teacher control * grades & & 0.924 & \\
\hline Pupils: integration * grades & & 0.937 & \\
\hline Pupils: bullying * grades & & 1.038 & \\
\hline Pupils: violence * grades & & 0.897 & \\
\hline \multicolumn{4}{|l|}{ Random effects } \\
\hline$\sigma_{\text {Uuj }}($ constant) & $0.372^{* * *}$ & - & $0.241^{* * *}$ \\
\hline$\sigma_{u 1 j}$ (grades) & $0.068^{* * *}$ & - & $0.063^{* * *}$ \\
\hline Explained variance (\%) & 11.1 & - & 12.8 \\
\hline
\end{tabular}

${ }^{*} p<.05,{ }^{* *} p<.01,{ }^{* * *} p<.001$. 
frequently, the risk is heightened even further. Hence at schools where teachers more frequently engage in bullying, it is the poorer pupils who tend to be moved to stay away from school. This effect remains in place when further control variables are included in the model (Model 6a). This model also shows that the relationship between grades and truancy continues to vary significantly among schools.

\section{DISCUSSION}

The above analyses show that truancy is primarily influenced by factors that are to be found at the individual level. Hypotheses $4 \mathrm{a}$ to $4 \mathrm{c}$ are confirmed across the board. Negative childhood experience in the parental home, poor self-control and contact with friends who play truant all heighten the risk of truancy. The findings also show that, as suggested in Hypothesis 3, poor school performance is linked with truancy in the expected manner.

The hypotheses that focus on the influence of the school environment are, by way of contrast, only confirmed in part. Thus the school environment, at least in the form captured here, plays a subordinate role when compared with individual factors. Nonetheless, two conclusions can be drawn: Firstly, in schools where teaching staff exercise strict controls on student absenteeism, fewer students play truant by themselves (Hypothesis 1). A culture of observance and monitoring inhibits both violent behaviour (see e.g. Baier and Pfeiffer 2011) and truancy. This applies to all students and thus also to those who perceive lesser levels of control by teachers: The effect of the degree of control within the school remains when controlled for individual perceptions. Secondly it is confirmed that teachers who behave aggressively towards students (e.g. being mean to them) tend to drive students to play truant (Hypothesis $2 b$ ). Furthermore, teaching staff who engage with students go hand in hand with lesser student readiness to play truant (Hypothesis 2a). However, the two effects do not hold stable in multivariate models, thus supporting the assumption that the effect of responsiveness or bullying from teacher is indirect. In the example of teachers bullying this means that in schools where teachers often adopt an aggressive, bullying attitude towards students, it is more likely that a student will fall victim to those attacks. Truancy than is seen more frequently among students who have experienced such attacks.

Aggressive behaviour demonstrated by teachers is also relevant in another respect. As assumed in
Hypothesis $3 a$, it influences the effect of poor school performance. In schools with high levels of teacherstudent bullying, poor school performance influences truancy, i.e. poorer-performing students have an enhanced incentive to stay away from school. This could be explained by the fact that the teachers' attacks are concentrated on students who perform badly, with the students perceiving both a slight on their abilities and on their person. Other school characteristics have no influence on the effects of school performance. It cannot be said, therefore, that positive teacher-student and student-student relations help to keep less successful students in school.

Hypotheses 2c and 2d could not be confirmed. While in bivariate analysis, a higher level of violence in school fosters truancy, when compared with teacherrelated school factors its influence is weaker, and it has no significance in a multivariate model. Closer studentstudent relations are thus equally as ineffective in preventing truancy as a higher level of aggression among students is in promoting it. This can perhaps be explained in that above-average social cohesion does not necessarily mean that specific individuals are well integrated into a network of friends. While greater cohesion can exist among the majority of students, a small number may be excluded and could thus be especially prone to truancy. It is therefore necessary to investigate not only the average level of cohesion, but the possible formation of cliques from which individual students might be excluded. It could also be that members of a group with whom a student is friendly at school demonstrate deviant behaviour themselves. That a friendship exists does not indicate the type of students in a network of friends. It would thus make sense to look at the traits demonstrated by a student's friends. Students could then be segregated according to whether they belong to conforming social groups at school, or are friends with students who show deviant behaviour. One method which allows such differentiated analysis of school friendships is social network analysis. While this has not been used in studies on truancy to date, it has been used in studies on delinquent behaviour (see e.g. Haynie, 2001).

One possible explanation why a higher level of aggression among students does not influence truancy could be that truants are not necessarily affected by such negative actions. They attend school less frequently, and their deviant behaviour may afford them a higher status that prevents them from being a primary target. This is in line with the results of a schools survey in which only 4.6 percent of truants said that 
they stayed away from school because they were treated meanly by other students; only 2.6 percent cited being threatened with violence (Baier et al. 2006: 273). Those students affected by bullying and violence may tend to internalise the experience to a greater degree.

Although the analyses have brought the relationship between school environment and truancy into the spotlight, their methodological shortcomings must not be overlooked. It is important to point out that the hypotheses were only tested using a cross-sectional survey rather than a longitudinal study. This provides evidence of relationships but not of effects. This is all the more problematic in that the school characteristics were aggregated from individual responses, so that measurement of school characteristics per se is dependent on individual responses. It would be desirable, therefore, for either school-related characteristics to be surveyed at an earlier juncture or for these characteristics to be measured by other means (e.g. observation or teacher survey). Additionally it must be remembered that the study used to test the hypotheses was not designed to analyse school-related influencing factors of truancy. What this means is that in each school, only a few students (perhaps just a single class) and then only ninth-grade students were questioned. School-level characteristics can only be captured in this way to an insufficient extent. Furthermore account must be taken of the fact that some students who demonstrated the observed behaviour were not surveyed, meaning the truants who stayed away on the day of the survey. The suggested relationships can thus only be tested for the truants who were actually present on the day. It cannot be ruled out that the findings would be different if the survey could include all the students who played truant on the survey day.

\section{REFERENCES}

Attwood, Gaynor and Ppaul Croll. 2006. "Truancy in Secondary School Pupils: Prevalence, Trajectories and Pupil Perspectives." Research Papers in Education 21: 467-84. https://doi.org/10.1080/02671520600942446

Baier, Dirk. 2011. Jugendliche als Opfer und Täter von Gewalt in Wolfsburg [Adolescents as Victims and Perpetrators of Violence in Wolfsburg]. Hanover: KFN-Forschungsbericht.

Baier, Dirk and Christian Pfeiffer. 2011. "Wenn Opfer nicht zu Tätern werden. Beeinflussen Bedingungen der Schulklasse den Zusammenhang von innerfamiliären Gewalterfahrungen und eigener Gewalttäterschaft?" [" When Victims Do Not Become Perpetrators. Do the Conditions Prevailing in a Class at School Have an Impact on the Connection Between Exposure to Parental Violence and Later Violence?"] Trauma und Gewalt 5: 6-19.
Baier, Dirk, Christian Pfeiffer, Julia Simonson, and Susann Rabold. 2009. Jugendliche in Deutschland als Opfer und Täter von Gewalt [Adolescents in Germany as Victims and Perpetrators of Violence]. Hanover: KFN-Forschungsbericht Nr. 107.

Baier, Dirk, Christian Pfeiffer, Michael Windzio and Susann Rabold. 2006. Schülerbefragung 2005: Gewalterfahrungen, Schulabsentismus und Medienkonsum von Kindern und Jugendlichen. [Students Survey 2005: Experiences of Violence, Truancy, and Media Consumption of Children and Adolescents]. Hanover: Forschungsbericht.

Gottfredson, Michael R. and Travis Hirschi. 1990. A General Theory of Crime. Stanford: University Press.

Grasmick, Harold G., Charles R. Tittle, , Robert J. Bursik, and Bruce J. Arneklev. 1993. "Testing the Core Empirical Implications of Gottfredson and Hirschi's General Theory of Crime." Journal of Research in Crime and Delinquency 30: 5-29. https://doi.org/10.1177/0022427893030001002

Haynie, Dana L. 2001. "Delinquent Peers Revisited: Does Network Structure Matter?" American Journal of Sociology 106: 10131057. https://doi.org/10.1086/320298

Hirschi, Travis. 1969. Causes of Delinquency. Berkeley: University of California Press.

Kimberly, Henry L. and David H. Huizinga . 2007. "School-related Risk and Protective Factors Associated with Truancy among Urban Youth Placed at Risk." The Journal of Primary Prevention 28, 505-519. https://doi.org/10.1007/s10935-007-0115-7

Lee, Everett S. 1966. "A Theory of Migration." Demography 5: 47-57. https://doi.org/10.2307/2060063

Lee, Valerie E. and David T. Burkam. 2003. "Dropping Out of High School: The Role of School Organization and Structure." American Educational Research Journal 40: 353-393. https://doi.org/10.3102/00028312040002353

Loeber, Rolf and Thomas Dishion. 1983. Early Predictors of Male Delinquency: A Review. Psychological Bulletin 94: 68-99. https://doi.org/10.1037/0033-2909.94.1.68

McNeal, Ralph B. 1999. "Parental Involvement as Social Capital: Differential Effectiveness on Science Achievement, Truancy, and Dropping Out." Social Forces 78: 117-144. https://doi.org/10.1093/sf/78.1.117

Moos, Rudolf H. and Bernice S. Moos. 1978. "Classroom Social Climate and Student Absences and Grades." Journal of Educational Psychology 70: 263-269. https://doi.org/10.1037/0022-0663.70.2.263

Mounteney, Jane, Siren Haugland and Arvid Skutle. 2010. "Truancy, Alcohol Use and Alcohol-Related Problems in Secondary School Pupils in Norway." Health Education Research 25: 945-954. https://doi.org/10.1093/her/cyq044

Rabold, Susann and Dirk Baier. (2007). „Delinquentes Verhalten von Jugendlichen. Zur differentiellen Bedeutsamkeit verschiedener Bedingungsfaktoren“ [,Delinquent Behavior of Adolescents. About the Differential Significance of Various Influencing Factors"]. Sozialwissenschaftlicher Fachinformationsdienst Kriminalsoziologie und Rechtssoziologie 2: 9-42.

Reid, Ken. 2005. "The Causes, Views and Traits of School Absenteeism and Truancy: An Analytical Review." Research in Education 74: 59-82. https://doi.org/10.7227/RIE.74.6

Reynolds, David, D. Jones,, S. St. Leger and Stephen Murgatroyd. 1980. School Factors and Truancy. In Out of School, eds. Lionel Hersov and lan Berg, Chichester: Wiley.

Ricking, Heinrich. 2003. Schulabsentismus als Forschungsgegenstand [Truancy as a Research Topic]. Oldenburg: Bibliotheks- und Informationssysteme der Universität Oldenburg. 
Sampson, Robert J., Stephen W. Raudenbush and Felton Earls. 1997. "Neighborhoods and Violent Crime: A Multilevel Study of Collective Efficacy." Science 277: 918-924. https://doi.org/10.1126/science.277.5328.918

Shaw, Clifford R, and Henry D.McKay. 1969[1942]. Juvenile Delinquency and Urban Areas: A Study of Rates of Delinquency in Relation to Differential Characteristics of Local Communities in American Cities (Revised Edition). Chicago: University of Chicago Press.

Snijders, Tom A.B. and Roel Bosker. 2011. Multilevel Analysis: An Introduction to Basic and Advanced Multilevel Modeling. Thousand Oaks: Sage. https://doi.org/10.1007/978-3-642-04898-2 387

Sutherland, Edwin H. 1924. Principles of Criminology. Chicago, IL: University of Chicago Press.

Vazsonyi, Alexander T., Lloyd E. Pickering, Marianne Junger and Dick Hessing. 2001. "An Empirical Test of a General Theory of Crime: A Four-Nation Comparative Study of Self-Control and the Prediction of Deviance." Journal of Research in Crime and Delinquency 38: 91-131. https://doi.org/10.1177/0022427801038002001
Wagner, Michael, Inke Dunkake and Bernd Weiß. 2004. "Schulverweigerung. Empirische Analysen zum abweichenden Verhalten von Schülern“ [„Truancy. An Empirical Analysis oft he Deviant Behavior of Pupils"]. Kölner Zeitschrift für Soziologie und Sozialpsychologie 56: 457-489. https://doi.org/10.1007/s11577-004-0074-4

Warr, Mark 2002. Companions in Crime: The Social Aspects of Criminal Conduct. Cambridge: Cambridge University Press. https://doi.org/10.1017/CBO9780511803956

Wilmers, Nicola, Katrin Brettfeld, Dirk Enzmann, Dagmar Schaefer, Karin Herbers, Werner Greve and Peter Wetzels. 2002. Jugendliche in Deutschland zur Jahrtausendwende: Gefährlich oder gefährdet? [Adolescents in Germany at the Turn of the Millennium: Dangerous or Endangered]. BadenBaden: Nomos.

Wood, Peter B., Betty Pfefferbaum and Bruce J. Arneklev. 1993. "Risk-Taking and Self-Control: Social Psychological Correlates of Delinquency." Journal of Crime and Justice 16: 111-130. https://doi.org/10.1080/0735648X.1993.9721481

DOI: http://dx.doi.org/10.6000/1929-4409.2016.05.18

(C) 2016 Dirk Baier; Licensee Lifescience Global.

This is an open access article licensed under the terms of the Creative Commons Attribution Non-Commercial License (http://creativecommons.org/licenses/by-nc/3.0/) which permits unrestricted, non-commercial use, distribution and reproduction in any medium, provided the work is properly cited. 